\title{
DEEP NECK INFECTIONS AMONG THE POPULATION ATTENDING AT NOBEL MEDICAL COLLEGE BIRATNAGAR
}

\author{
Ravi Bhushan Suwal, Meenakshi Basnet, Rabin Acharya, Kamal Parajuli
}

\begin{abstract}
Introduction: The advent of diagnostic tools and antibiotic, incidence of deep neck infections have been reduced but still infections are seen today with definite potential for significant morbidity and mortality. The purpose of this study was to review predisposing factors, bacteriology, treatment and possible complications.

Study design: A retrospective review was conducted of patients who were diagnosed as deep neck infections in Department of Otolaryngology at Nobel Medical College from between August 2010 to December 2014. Total 90 patients were included in this study. Their demography, etiology, underlying systemic diseases, infection locality, causative organism and modality of treatment were reviewed.
\end{abstract}

Results:Of 90 patients, 65 were male and 25 were female. Fourty eight patients were in age range of 20-40 years and which was the most affected age group in our series.Odontogenic and parotid infections were the most frequent causes for deep neck infections. Submandibular space and cervical lymphnodewere most affected site in neck. Staphylococcus aureus and mixed flora were organisms commonly isolated from culture. The most commonly found systemic diseases were diabetes mellitus and systemic arterial hypertension. In our series 18 patients (20\%) had associated diabetes mellitus (DM).The most frequently encountered complication was upper airway obstruction. In our series 3 patients undergone tracheostomy; one patient each with Ludwig's angina, necrotizing fasciitis and retropharyngeal abscess.

Conclusions: It is essential to pay attention to older patients associated with systemic diseases (DM, HTN, Chronic kidney disease), because they can often progress to life threatening complications. The mainstays of treatment are maintenance of the airway, fluid resuscitation, intravenous antibiotics, and timely adequate surgical drainage. Therapeutic needle aspiration and conservative medical treatment are effective in selective cases such as those with minimal abscess formation.

Keywords: Deep neck infection, Odontogenic, Diabetes mellitus, airway obstruction

\section{Introduction}

Deep neck infections (DNI) are bacterial infections originating from the upper aerodigestive tract and involving the deep neck spaces. ${ }^{1}$ DNI was a serious and potentially life-threatening infection in the past. With improved diagnostic investigations, widespread availability of antibiotics and early surgical intervention today, the mortality rate has decreased significantly compared with that of early reports. ${ }^{2-4}$ However, when not diagnosed and treated appropriately, these infections progress rapidly and are associated with high morbidity and mortality. Complications resulting from DNI are usually 
due to delay in treatment. These may include upper airway obstruction, jugular venous thrombosis, descending mediastinitis, septic shock and death.

\section{Material and Method}

The study was a retrospective analysis of patients diagnosed with deep neck infections in the Department of Otolaryngology at Nobel Medical College and Teaching Hospitalbetween August 2010 to December 2014. Data were collected from $10^{\text {th }}$ April2015 to June $10^{\text {th }} 2015$ after the ethical clearance from IRC, Noble Medical College.

Total 90 patients were included in this study. Their demography, etiology, underlying comorbid conditions, infection locality, causative organism and modality of treatment were reviewed.

Computed tomography of the neck and thorax and surgical reports were used for establishing which of neck spaces were involved by infection.

The involved spaced were divided according to the description published previously ${ }^{7,8}$ and included lugwig's angina and following spaces in our series: submandibular, parapharyngeal, retropharyngeal, anterior cervical, parotid and masticator space.

Data were tabulated for descriptive and statistical analysis. The SPSS version 16.0 software was used.

\section{Results}

Of 90 patients, 65 were male and 25 were female. Their ages ranged from 1-79 years, with a mean age of $34.3 \pm 17.99$ years. Forty eight patients were in age range of 20-40 years and which was the most affected age group in our series as indicated in Figure 1.

Fig.1 Age distribution

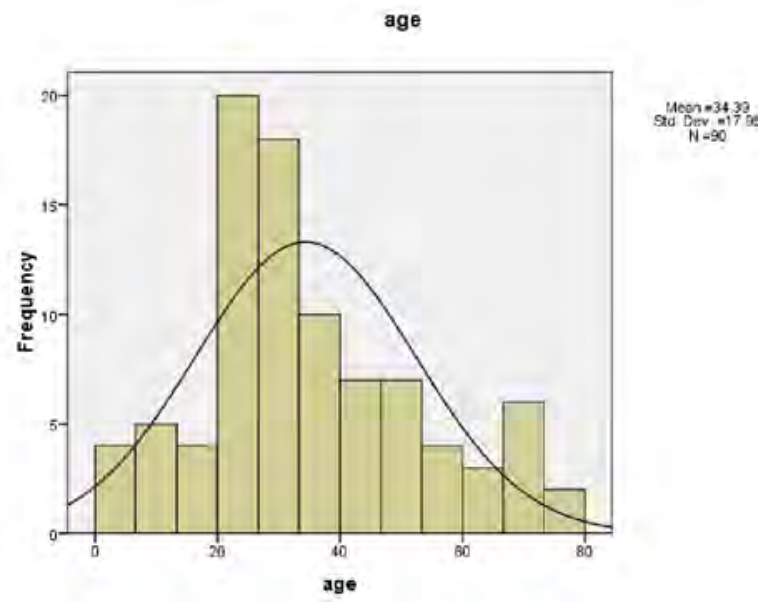

Identification and diagnosis of involved spaces/sites was done with the help of various radiological investigations particularly ultrasonogram and if required CT scans with contrast enhancement. The distribution of the spaces/sites is shown in table 1 .

Table1. Spaces and site involved by abscess

$\begin{array}{lll}\text { Spaces/Sites of abscess } & \text { No. } & \text { \% } \\ \text { Submandubular space } & 19 & 21.1 \\ \text { Suppurativelymphadenitis } & 14 & 15.6 \\ \text { Parotid space } & 12 & 13.3 \\ \text { Peritonsillar space } & 10 & 11.1 \\ \text { Masticator space } & 8 & 8.9 \\ \text { Parapharyngeal space } & 8 & 8.9 \\ \text { Tubercular abscess } & 7 & 7.7 \\ \text { Infected cyst } & 5 & 5.6 \\ \text { Necrotizing fasciitis } & 3 & 3.3 \\ \text { Ludwig's angina } & 2 & 2.2 \\ \text { Anterior cervical abscess } & 1 & 1.1 \\ \text { Retropharyngeal abscess } & 1 & 1.1 \\ \text { Total } & 90 & 100\end{array}$

The main reason for deep neck abscessin our series was odontogenic (19 patients), which accounted for $21.1 \%$ of total cases followed by parotitis (12 cases, 13.3\%). Ten cases $(11.1 \%)$ are afflicted after tonsillar infection, 7 cases $(7.8 \%)$ after tubercular infection, 6 cases $(6.7 \%)$ affected following URTI, 5 patients $(5.6 \%)$ occurred as the consequences of congenital cervical cyst infection. Skin infection and traumatic causes are responsible for 3 case $(3.3 \%)$ and 2 cases $(2.2 \%)$ respectively but in 26 cases $(28.8 \%)$ of 
abscesses cause was unknown as depicted in Table 2.

\begin{tabular}{lll} 
Table2. Etiological factors & \multicolumn{3}{c}{ identified } \\
Etiology & No. & $\%$ \\
Odontogenic & 19 & 21.1 \\
Parotitis & 12 & 13.3 \\
Tonsillar infection & 10 & 11.1 \\
Tuberculosis & 7 & 7.8 \\
URTI & 6 & 6.7 \\
Congenital cervical cyst & 5 & 5.6 \\
Skin infection & 3 & 3.3 \\
Traumatic & 2 & 2.2 \\
Unknown & 26 & 28.8 \\
Total & 90 & 100
\end{tabular}

Twenty seven patients (30\%) had underlying systemic disease. Their ages ranged from 27 to 78 years with a mean age of 54years. There were 18 patients $(66.6 \%$ of 27 cases $)$ with diabetes mellitus (DM), 5 patients $(18.5 \%$ of 27 cases) with systemic arterial hypertension, 3 cases $(11.1 \%$ of 27 cases) with chronic kidney disease and 1 case $(3.7 \%$ of 27 cases) with hepatitis as shown in Fig.2

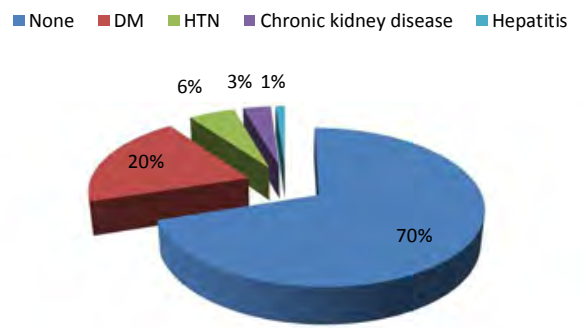

Fig. 2 Co- morbid disease conditions

There were only 2 patients $(7.4 \%)$ who had associated co-morbid condition with age $<35$ years while 25 patients $(92.6 \%)$ were age $>35$ years suggesting the patients with underlying co-morbid condition have a higher mean age. This was statistical significant with $p$ value of $<0.05$. Table 3 .

$\begin{array}{rllll}\text { Age } & \begin{array}{l}\text { Co-morbid } \\ \text { present }\end{array} & \begin{array}{l}\text { Co-morbid } \\ \text { absent }\end{array} & \text { Total } & \text { Pvalue } \\ <35 & 2 & 56 & 58 & \\ >35 & 25 & 7 & 32 & <0.00 \\ & 27 & 63 & 90 & \end{array}$

Except for tubercular abscess all the patients were undergone culture and sensitivity test.
Out of total 83 cases (excluding tuberculosis), results of bacterial cultures for 65 cases (78.3\% of 83 cases) were positive. Among the positive cultures, staphylococcus aureus was most significant pathogen isolated in 35 cases (42.1\%) followed by mixed flora in 11 cases (13.2\%). Eighteen cultures had no bacterial growth after 48 hours of incubation as described in Table 4.

\begin{tabular}{llc}
\multicolumn{2}{l}{ Table 4.Causative organism of abscess } \\
$\begin{array}{l}\text { Organism } \\
\text { Staphylococcus }\end{array}$ & No & $\%$ \\
$\begin{array}{l}\text { aureus } \\
\text { Mixed flora }\end{array}$ & 35 & 38.9 \\
$\begin{array}{l}\text { Streptococcus } \\
\text { viridans }\end{array}$ & 11 & 12.2 \\
$\begin{array}{l}\text { Mycobacterium } \\
\text { tuberculosis }\end{array}$ & 8 & 8.9 \\
$\begin{array}{l}\text { Streptococcus } \\
\text { pyogens }\end{array}$ & 7 & 7.8 \\
$\begin{array}{l}\text { Enterococcus fecalis } \\
\text { E. coli }\end{array}$ & 3 & 6.7 \\
No growth & 2 & 3.3 \\
& 18 & 2.2 \\
\end{tabular}

The entire patient received antimicrobial therapy. Out of 90 patients, 80patients $(88.8 \%)$ underwent surgical drainage, 3 patients $(3.3 \%)$ underwent surgical drainage and tracheostomy and other 7 patients (7.7\%)underwent serial needle aspiration and anti-tubercular therapy (ATT). Except the patient with tuberculosis, rests of the all were admitted and received parenteral antibiotics. After doing surgical intervention and parenteral antibiotics for few days all patients were discharged in stable condition as shown in Fig.3

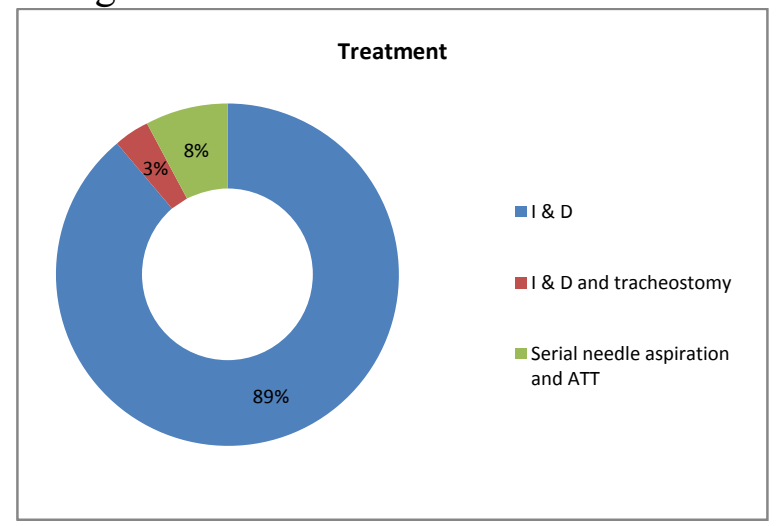




\section{Discussion}

The fascial spaces of the neck are potential spaces between the layers of the cervical fasciae. In the normal state, the spaces do not exist but present as loose connective tissue that may be digested and displaced by and infective process. A thorough knowledge of the anatomy of these fasciae and spaces is essential to understand the etiology, presentation, and potential complications of a specific space infection. It is also important to perform proper radiological investigation and to institute the most effective treatment.

The mean age that was affected most by deep neck infections in the literature varied from 36 to 57 years. ${ }^{1,9,10}$ which was comparable to our finding and this can be attributed to intravenous drug abuse or external blunt trauma which usually occurs in the young or middle aged. The disease was more common in case of males, as many studies have reported. ${ }^{3,4,11,12}$

The predominantly involved space in this study was submandibular space. Which is consistent with Raga, Meher ${ }^{13,}{ }^{14}$ and Ghandomi and RegueroVillarin ${ }^{15}$, 16 who introduced the submandibular space as the most prevailing one while disagrees with Parhiscar's and Huan's studies which announced parapharyngeal space as the prevalent space. ${ }^{4,17}$

DNI originate from a variety of sites in the head and neck; these include the teeth, the salivary glands and the tonsils. The teeth are the most common primary site $(31 \%-80 \%)$, followed by tonsils $(1.5 \%-3.4 \%) .3,4, \quad 11$, ${ }^{12}$ Odontogenic conditions were the most common cause in our series $(21.1 \%)$, and followed by parotid disease $(13.3 \%)$. The cause remained unknown in 26 patients (28.8\%) even after a detailed clinical history, physical examination and radiological studies. Other studies have also shown a significant proportion (16\%-39\%) of neck abscess of unknown origin. ${ }^{3,4,12}$ Infections from teeth may readily spread into sublingual, submandibular and masticator space because of its close anatomic proximity. That's why the submandibular space was most frequently involved space as so far.

The microbiological characteristics of DNIs have been studied extensively in the past as resistance rates to conventional antibiotics have become a concern. Common culprits for DNIs include the Streptococcus viridans, Beta hemolytic streptococci, Staphylococcus aureus, K. pneumonia, anaerobic Bacteroides, and Peptostreptococcus. ${ }^{2,3,4}$ In our study, among the positive cultures, staphylococcus aureus was most significant pathogen isolated in 35 cases $(42.1 \%)$ followed by mixed flora in 11 cases $(13.2 \%)$. Eighteen cultures (21.6\%) had no bacterial growth after 48 hours of incubation, this is a low rate compared to that of other authors (which has ranged from $27 \%-40 \%$ ). ${ }^{3,}{ }^{18}$ This is probably due to the indiscriminate use of antibiotics before coming to hospital. ${ }^{3}$

The treatment of deep neck infection consists of airway management, fluid resuscitation, antibiotic therapy, and surgical drainage of the abscesses. Surgical drainage should be performed without delay for cases with significant abscess formation seen on CT, impending complications, or not responding to medical treatment. If there is minimal pus collection and not at risk of complications, conservative management may be tried. Another important thing in a management of deep neck infection is associated co-morbid condition and that should be managed parallel to the management of deep neck abscess. ${ }^{10}$

Deep neck infections are very prone to complications, such as upper airway obstruction, lemierre'ssyndrome (thrombophlebitis of internal jugular vein), carotid artery psuedoaneurysm or rupture, plural effusion and septic shock. ${ }^{9,}{ }^{19,}{ }^{20}$ In our series, the most frequently encountered complication was upper airway obstruction. Authors reported a higher incidence of tracheostomies in Ludwig's angina abscesses 
(75\%) and retropharyngeal space abscess $(25 \%))^{2,4}$ In our series 3 patients undergone tracheostomy; one patient each with Ludwig's angina, necrotizing fasciitis and retropharyngeal abscess. Incidence of airway obstruction in our series was quite low as compared to other studies, probably because many of the patients were treated in the early stage of the disease.

The most commonly found systemic diseases were diabetes mellitus (DM) and systemic arterial hypertension. The literature has reported a $16 \%-20 \%$ incidence of diabetes ${ }^{3}$. In our series again $20 \%$ of patients had associated diabetes mellitus. It results in a defect in the host's immune function such as cellular immunity complement activation and polymorphonuclear neutrophil function and that increase the risk of vascular complications and the episodes of infection. ${ }^{21}$, ${ }^{22}$ Out of 3 patients who were undergone tracheostomy for airway obstruction, two of them were known diabetes mellitus. Therefore when dealing with deep neck infections, more attention should be paid to patients with DM or other associated systemic diseases. ${ }^{9,10}$

Prompt recognition and treatment of deep neck infections are essential for an improved prognosis. Thus, key elements for improved results are the identification of morbid factors, signs and symptoms, and computed tomography.

Conclusions

The current study enables us to conclude that Odontogenic cause is the most common for DNI and submandibular and parotid areas are the most frequently involved spaces. Staphylococcus aureus and mixed flora are the main microorganisms involved in this condition. It is essential to pay attention to patients associated with systemic diseases (DM, HTN, chronic kidney disease), because they can often progress to life threatening complications. The mainstays of treatment are maintenance of the airway, intravenous antibiotics, and timely adequate surgical drainage.

\section{REFERENCES}

1. Suebara AB, Goncalves AJ, Alcadipani FA, Kavabata NK, Menezes MB. Deep neck infection-analysis of 80 cases. Brazillian Journal of Otorhinolaryngology 2008; 74(2); 253-9.

2. Har-El G, Aroesty JH, Shaha A, Lucente FE. Changing trends in deep neck abscess. A retrospective study of 110 patients. Oral Surg Oral Med Oral Pathol 1994; 77:446-450.

3. Sethi DS, Stanley RE. Deep neck abscesseschanging trends. J LaryngolOtol 1994; 108:138143.

4. Parhiscar A, Har-El G. Deep neck abscess: a retrospective review of 210 cases. Ann OtolRhinolLaryngol 2001; 110:1051-1054.

5. ColmeneroRuize C, Labajo AD, Yanez Vilas I, Paniagua J: Thoracic complications of deeply situated serious neck infections. J CraniomaxillofacSurg1993, 21:76-81.

6. Beck HJ, Salassa JR, McCaffey TV, Hermans PE: Life-threatening soft tissue infections of the neck. Laryngoscope 1984, 94:354361.

7. Marra S, Hotaling AJ. Deep neck infections. Am J Otolaryngol 1996; 17:287-298.

8. Scott BA, Stiernberg CM, Driscoll BP. Infections of the deep spaces of the neck. In: Bailey BJ, editor. Head and neck surgery otolaryngology, 3rd ed. Philadelphia: JB Lippincott; 2001. p 701-715.

9. Chen MK, Wen YS, Chang CC, Huang MT, Hsiao HC. Predisposing factors of life-threatening deep neck infection: logistic regression analysis of 214 cases. J Otolaryngol 1998; 27(3):141-4.

10. Chen MK, Wen YS, Chang CC, Lee HS, Huang MT, Hsiao HC. Deep neck infections in diabetic patients. Am J Otolaryngol 2000; 21(3):169-73.

11. Bahu SJ, Shibuya TY, Meleca RJ, Mathog RH, Yoo GH, Stachler RJ, et al. Craniocervical necrotizing fasciitis: an 11-year experience. Otolaryngol Head Neck Surg 2001;125(3):245-52.

12. Sakaguchi M, Sato $\mathbf{S}$, Ishiyama $\mathbf{T}$, Katsuno $\mathbf{S}$, Taguchi K. Characterizationand management of deep neck infections. Int J Oral Max Surg 1997;26(2):131-4.

13. Raga AJ, Aziz SR, Ziccardi VB. Microbiology and antibiotic sensitivities of head and neck space infections of odontogenic origin. $\mathrm{J}$ Oral MaxillofacSurg 2006; 64(9): 1377-80.

14. Meher R, Jain A, Sabharwal A, Gupta B, Singh I, Ajarwal AK. Deep neck abscess: A prospective 
study of 54 cases. J LaryngolOtol 2005; 119 (4): 299-303.

15. Ghandomi B, Musavi SA. Epidemiology and etiology of deep neck abscess. Iranian journal of otorhinolaryngology 2008; 20(1): 39-44.

16. RegueiroVillarin SV, AzquezBarro JC, Herranz Gonzalez-Botas J. Deep neck infections: Etiology, bacteriology and treatment. ActaOtorrinolaringolEsp 2006; 57(7): 324-8.

17. Huang TT, Liu TC, Chen PR, Tseng FY. Deep neck infection: An analysis of 185 cases. Head Neck Surg 2004; 26: 854-60.

18. Lin C, Yeh FL, Lin JT, Ma H, Hwang CH, Shen BH, et al. Necrotizing fasciitis of the head and neck: an analysis of 47 cases. PlastReconstrSurg 2001;107 (7):1684-93.

19. Estrera AS, Landay MJ, Grisham JM, Sinn DP, Platt MR. Descending necrotizing mediastinitis. SurgGynecolObstet 1983; 157:545-552.

20. Beck HJ, Salassa JR, McCaffrey TV, Hermans PE. Life threatening soft tissue infections of the neck. Laryngoscope 1984; 94:354-362.

21. Hostetter MK. Handicaps to host defenses: effects of hypoglycemia on C3 and Candida albicans. Diabetes 1990; 39:271-275.

22. Delamaire M, Maugendre D, Moreno M, et al. Impaired leukocyte functions in diabetic patients. Diabetic Med 1997; 14:29-34. 8

Correspondence Address: DR. Ravi BhushanSuwal, Lecturer, Nobel Medical College, Biratnagar aarbiyesh@gmail.com 